Mary Ann Lyons

\title{
The interrogation of Matthew Barnewall, an Irish jansenist imprisoned in the Bastille, 1712-13
}

\section{Introduction}

On 25 May 1712, Matthew Barnewall, a priest of Dublin diocese, was one of two clerics detained in the Bastille in Paris on a charge of Jansenism. ${ }^{1}$ He and his associate, Saint Jean de Pardiac ${ }^{2}$, a priest of the diocese of Condom in south-west France, were accused of having travelled throughout several dioceses in France, under pretext of distributing alms, in order to circulate books that were contrary to Catholic teaching and suspected of being jansenist. Barnewall was accused of associating with the French Oratorian theologian and spiritual writer, Pasquier Quesnel (1634-1719), a close confidant of one of France's leading jansenist scholars, Antoine Arnauld (1612-94). He was also alleged to have had contact with other leading figures in the jansenist cabal.

Born into an Old-English gentry family $c .1659$, Matthew Barnewall was a native of Gracedieu ${ }^{3}$ in north County Dublin. Nothing is known about his upbringing or initial education. When he arrived in France in 1674 and began his studies in the University of Paris, the country was gripped by the second jansenist controversy in which Irish clerical students at the University had been embroiled. ${ }^{4}$ In 1660 , King Louis XIV announced to the Assembly of Clergy that he regarded the extirpation of jansenism a matter of conscience. A formulary was subsequently prepared, containing a condemnation of the five propositions extracted from Jansen's Augustinus (Louvain, 1640), and every ecclesiastic, male and female, was obliged to sign it. Owing to the Paix de l'Élise (1668-79), the convent at PortRoyal-des-Champs, the spiritual and symbolic headquarters of Jansenism,

I See Préfecture de Police, Paris, Archives Prisons Royales, série AA5, Bastille II, notes sur les prisonniers, 1661 à 1755, f. 344; série AA6, Bastille III, notes sure les prisonniers, 1703 à 1724, f. 488 . 2 De Pardiac was subsequently transferred to another prison, Saint-Lazaire, on 27 December 1712 for three months. See Bibliothèque de l'Arsenal, Paris (B. de l'A.) Archives de la Bastille, MS 10602, ff 87, 90-91, 92-4, 117-18, 192-3; François Ravaisson (ed.), Archives de la Bastille, documents inédits (17 vols, Paris, 1866-91), xiii, pp 246. 3 Gracedieu was part of the Barnewall ancestral properties, which also included Turvey and Fieldstown. It is situated in the modern barony of Balrothery East, in the civil parish of Lusk. 4 For discussions of Irish involvement in jansenist controversies, see Joseph S. O'Leary, 'The Irish and jansenism in the seventeenth century' in Liam Swords (ed.), The Irish-French connections, 1578-1978 (Paris, 1978), pp. 21-43; Thomas O'Connor, 'The role of Irish clerics in Paris University politics, 1730-40' in History of Universities, xv (19979), pp 193-225; Priscilla O'Connor, 'Irish students in Paris faculty of theology: aspects of doctrinal controversy in the ancien régime, 1730-60' in Arch. Hib., liii (1998), pp 85-97; idem, 'Irish clerics and French politics of grace: the reception of Nicholas Madgett's doctoral theses, 1732' in Thomas O'Connor and Mary Ann Lyons (eds), Irish migrants in Europe after Kinsale, 1602-1820 (Dublin, 2003), pp 182-202. For a general introduction to the jansenist movement in France see William Doyle, Jansenism: catholic resistance to authority from the Reformation to the French Revolution (Basingstoke and New York, 2000). 
was placed under the protection and patronage of the duchesse de Longueville $(1619-79)^{5}$, a member of the royal family whose pious observance and fidelity Louis XIV respected. However, during that time, the foundations of the so-called 'second jansenism' 6 were set down. Resistance to the formulary was never entirely suppressed. Louis XIV was intensely irritated by the eruption of localised controversies concerning jansenism in some of France's more remote dioceses and by the fact that leading jansenist scholars continued to publish translations of scripture and books in the vernacular that departed from Tridentine discipline. Orthodox bishops and his Jesuit confessor fanned the king's suspicions. Within weeks of the duchesse de Longueville's death in 1679, the archbishop of Paris visited Port-Royal and declared it a centre of sedition. Louis forbade any further recruitment of novices and confessors at the convent in the hope that the existing community would eventually die out.

A year later a pamphlet entitled A Case of Conscience (1702) re-opened the jansenist controversy in France, Belgian officials arrested several leading jansenist exiles, among them Quesnel, and found thousands of incriminating documents which exposed the extent of the movement's network throughout provincial France as well as its connections with Rome. They also revealed the level of systematic co-ordination behind the ostensibly random production of jansenist publications. The shock of that discovery fundamentally transformed the king's attitude to jansenism. To him and to the catholic hierarchy in France, 'far from the obsession of a handful of ageing clerical eccentrics, the fight against the formulary looked more like an extensive international conspiracy reaching up to the highest levels of the Church.'7

Louis XIV's immediate reaction was to throw Quesnel's French associates into the Bastille. Following negotiations with the pope, a new bull, Vineam Domini (1705) declared that respectful silence was not an acceptable response to questions raised in the formulary and once again condemned jansenism. The archbishop of Paris, Cardinal Louis-Antoine de Noailles $\left(16_{51-1729}\right),{ }^{8}$ known for his devout principles and hostility to the Jesuits, was determined to ensure that the bull was accepted by the most strident opponents of the formulary, the nuns of Port-Royaldes-Champs. They refused, and in 1709, in order to prevent the convent from becoming a pilgrimage site, the sisters were dispersed. By 1711, the buildings were completely razed and the remains of those buried in the grounds of the convent disinterred. Responsibility for this draconian measure lay with Louis XIV himself and perhaps with his most zealous Jesuit confessor, Michel Le Tellier (1643-1719), who was appointed in 1709. Not content with the physical destruction of PortRoyal, Le Tellier wanted a definitive, unambiguous condemnation of jansenism. Acting on his advice, Louis asked Pope Clement XI for such a bull. Reluctantly,

5 Jean Lesaulnier and Antony McKenna (eds), Dictionnaire de Port-Ropal (Paris, 2004), pp 686-88. 6 Term used by Doyle in Jansenism, chap. 4. 7 Doyle, Jansenism, p. 43. 8 Lesaulnier and McKenna, Dictionnaire, pp 761-62. 
the pope acquiesced and a congregation commenced an exhaustive examination of Quesnel's Réflexions Morales in search of compromising propositions.

It was in this atmosphere of extreme intolerance of jansenism that Matthew Barnewall was arrested and imprisoned in the Bastille on 25 May 1712. He was just one of several high profile Irish clerics in France, including Philip O'Lonergan, John Callaghan, Malachy Kelly and Michael Moore who were believed to have espoused jansenist beliefs. ${ }^{9}$ However, it was the timing of the authorities' discovery of his peregrinations and the extent of his incriminating contacts with several individuals and institutions known to have strong jansenist associations that resulted in Barnewall's severe censure. While studying theology at the Sorbonne, Barnewall was taught by Professor Pirot (1631-1713) whose ideas were cited by the French professor of theology, Pierre Nicole (1625-95) to justify his jansenist views. ${ }^{10}$ Later in his career, Barnewall was appointed rector of the diocesan seminary in Grenoble by Cardinal Étienne Le Camus (1632-1707), a close friend of Quesnel and Arnauld." Although not a member of the Port-Royal community, the preacher Abbé Honoré Reynaud de Gaillard (1641-1727), who invited Barnewall to accompany Saint Jean de Pardiac on a tour of the diocese of Senlis in order to distribute alms and books, had ties with leading jansenists, including Blaise Pascal. ${ }^{12}$ Barnewall was found to have been in receipt of a letter from Quesnel during his sojourn in Grenoble. He also admitted that he had not signed the formulary, which created further grounds for suspicion of jansenist tendencies. The interception of a letter written by de Pardiac, in which the latter details his 'aventures évangéliques' and refers to the towns of Normandy in the same terms as St Paul spoke about pagan cities of Asia Minor, confirmed police suspicions regarding the two clerics' membership of a jansenist cabal. ${ }^{13}$

In late March 1712, the French secretary of state, Louis de Phélypeaux, comte de Pontchartrain (1643-1727) and the lieutenant of police in Paris, Marc René de Voyer de Paulmy (1652-1721), marquis d'Argenson, were awaiting the return of Barnewall and Saint Jean de Pardiac to Paris. Two ordres $d u$ roi had been issued for their immediate arrest. D'Argenson was to seize all papers belonging to the two priests, to interrogate the two in detail and to forward the text of their interrogations to the secretary of state. ${ }^{14}$ Having held a succession of legal offices at the French court prior to his appointment as lieutenant in 1697, d'Argenson had a reputation for being particularly severe and inflexible. His derision for exponents of jansenism was evident when he oversaw the destruction of the rural abbey of Port-Royal-des-Champs in 1711, earning him the title 'le destructeur de Port-Royal'. Spurred on by Pontchartrain's assurances that 'le roi a cette affaire

9 See O'Leary, 'The Irish and jansenism', pp 21-43; Chambers, Michael Moore c.1639-1726: provost of Trinity, rector of Paris (Dublin, 2005), pp 105-09. 10 O'Leary, 'The Irish and jansenism', p. 41; MM. Firmin Didot, Nouvelle biographie générale depuis les temps les plus reculés jusqu'à nos jours, xxx (Paris, 1862), pp 320-21. II See MM. Firmin Didot, Nouvelle biographie générale (Paris, xxx), pp 172-3; Lesaulnier and McKenna, Dictionnaire, pp 607-08, 847. 12 Lesaulnier and McKenna, Dictionnaire, p. 435. 13 Letter by Saint Jean de Pardiac, 4 June 1712 (B. de l'A., Archives de la Bastille, MS 10602, ff 163-66). 14 Pontchartrain to d'Argenson, 22 Mar. 1712 (François Ravaisson (ed.), Archives de la Bastille, documents inédits (17 vols, Paris, 1866-91), xiii, p. 24). 
fort à coeur' and that 'le succès et la diligence de votre part vous feront d'autant plus de mérite auprès de S[a] M[ajestie]', d'Argenson had the two clerics arrested and conveyed to the Bastille. ${ }^{15}$

Upon his admission to the Bastille, Barnewall's papers were confiscated ${ }^{16}$ and he was repeatedly interrogated throughout the months of June and July. ${ }^{17}$ D'Argenson's handling of the interrogations was closely monitored by Pontchartrain who demanded that he be fully briefed regarding their progress, stressing that the king paid 'une attention très sérieuse' to this particular case. ${ }^{18}$ On 8 June, Pontchartrain presented d'Argenson with a list of subjects upon which he was to carry out detailed interrogations on Barnewall and de Pardiac. He was to question them regarding their distribution of several suspect books about religion, notably jansenist texts, in Paris and throughout the provinces. They were also to be questioned regarding the many jansenist works that had been in circulation during the previous year. ${ }^{19}$ In conducting his interrogations of Barnewall, d'Argenson also displayed his preoccupation with the pursuit of persons falsely claiming noble titles; hence, his interrogation of Barnewall regarding his change of name to de Barneville. ${ }^{20}$

Meanwhile, news of the priests' arrest spread throughout Paris. Just as Pierre de Langle, bishop of Boulogne was sealing his letter to Cardinal de Noailles, dated 17 June, he received news of the arrest and imprisonment of the 'deux saints prêtres'. De Langle was perplexed by the report, admitting that 'si ce n'est qu'ils sont soupçonnés de jansenisme; Dieu sait ce que tout cela veut dire'. ${ }^{21}$ Several advocates of the two priests protested their innocence and lobbied for their release throughout June and July $1712 .{ }^{22}$ Like many prisoners in the Bastille, Barnewall was permitted to correspond with his associates. On 30 June, he wrote to the principal of his residence at the Collège de Boncourt, Mr Huré, asking him to return to Michael Moore his copy of Maldonatus' work on the gospels, which Moore had lent to him. He also asked Huré to send him a Latin Imitation of Christ by Thomas à Kempis, with an English Bible in octavo, covered in black, in order that he might search for the passages abused by the Protestants, thereby enabling him to counter their claims. ${ }^{23}$ On 19 July, Pontchartain again pressed d'Argenson for copies of the interrogations which, he said, 'le roi attend avec impatience'. ${ }^{24}$

15 Pontchartrain to d'Argenson, 26 Apr. 1712 (ibid.); Pontchartrain to d'Argenson, 27 Apr. 1712 (ibid.). Only those arrested by order of the king (by a lettre de cachet) were imprisoned in the Bastille, which served as a state prison. In the main, it was reserved for the nobility and intellectuals, and the number of prisoners was always small: a total of forty were detained during the reign of Louis XIV. See Jacques Hillairet, Connaissance du vieux Paris, 3rd edn. (Lonrai, s.d.), p. 11.16 B. de l'A., Archives de la Bastille, MS 10602, f. 162 . I7 The texts of his interrogations on 18 June and 14 July 1712 along with other fragments survive. See B. de l'A., Archives de la Bastille, MS 10602, ff 96-97, 120-21, 126-8, 132-41. I8 Pontchartrain to d'Argenson, 1 June 1712 (Ravaisson (ed.), Archives de la Bastille, xiii, pp 24-5). 19 Pontchartrain to d'Argenson, 8 June 1712 (ibid.). 20 See O'Leary, 'The Irish and jansenism', pp 40-41; François Bluche, Dictionnaire du Grand Siècle (Paris, 1990), p. 103. 2I Pierre de Langle, évêque de Boulogne to Cardinal de Noailles, 17 June 1712 (ibid., p. 25). 22 Letters by Demartin, 5 June and 21 July 1712 (B. de l.'A., Archives de la Bastille, MS 10602, ff 117-18, 192-3); letter by a Paris-based lawyer named Marais, 1712 (Ravaisson (ed.), Archives de la Bastille, documents inédits, xiii, p. 25). 23 De Barneville à Mr Huré, 30 June (B. de l'A., Archives de la Bastille, MS 10602, ff 130-1). 24 Pontchartrain to d'Argenson, 19 July 1712 (Ravaisson (ed.), Archives de la Bastille, documents inédits, xiii, p. 26). 
By mid-June 1713, the king had indicated his willingness to see Barnewall released, and on 27 June, all his papers were returned to him and he left the Bastille. ${ }^{25}$ During his imprisonment tension concerning jansenism had not abated, and less than three months later, Pope Clement XI finally issued the resoundingly unambiguous bull Unigenitus, which categorically denounced 101 of Quesnel's propositions. All catholics were forbidden to read, copy or use the Réflexions Morales on pain of excommunication. ${ }^{26}$ However, Barnewall, who lived into his late seventies, continued to mix in jansenist circles and became a more belligerent supporter of the movement before his death in 1738. One contemporary, who remarked his great piety and zeal, noted that 'il observait un grand silence et travaillait beaucoup à la concorde des écritures'. ${ }^{27}$ Around 1731 he became involved in extremist popular jansenism through his association with the convulsionnaires, a group that had its origins in the cult surrounding the death and burial of a jansenist deacon, François de Pâris at St Médard cemetery, in Paris, in 1729. Buoyed up by escalating popular interest in de Pâris and the growing sense of expectation of miraculous happenings at his grave, jansenist groups in the city exploited these developments. Barnewall was associated with one of the more radical of these sects, which was led by 'Frère Augustin' or Jean Robert Cosse, who advocated an increasingly extra-legal stance in the pursuit of his activities.

On 12 January 1736 Barnewall and a group of 'Augustinistes' were arrested during a pilgrimage to the former home of jansenism, Port-Royal. During his subsequent imprisonment in the Conciergerie du Palais in Paris, he wrote his Profession de foy in which he set out his blatantly jansenist views and denounced the recantation of jansenism that had been extracted from him when he was incarcerated in the Bastille. Mathew Barnewall died in the Conciergerie in $1738 .^{28}$ His interrogation is valuable for the insights it provides into the vicissitudes of an Irish cleric's career, detailing the circumstances of his migration to France, his education, his ongoing connections with Ireland and the impact of changes in Irish political and ecclesiastical life on the direction of that career. Like a number of Irish clerics who trained in France, Barnewall spent virtually all his adult life ministering in French dioceses. This interrogation is especially useful as it offers a rare perspective on the variety of activities in which these clerics were engaged. Lastly, the text is particularly revealing regarding the stubborn participation of an Irish priest in the clandestine jansenist movement.

25 Certificate signed by Barnewall, 27 June 1703 [1713] (B. de l'A., Archives de la Bastille, MS 10602, fo. 162). 26 Antoine Adam, Du mysticisme à la révolte: les jansénistes du XVIIe siècle (Paris, 1968), pp 322-30; J.H. Shennan, Louis XIV (London, 1986), p. 31; Richard Wilkinson, Louis XIV, France and Europe, 1661-1715 (London, 1998), p. 46; Doyle, Jansenism, chap. 5. 27 Manuscit à la Bastille, 8ème lettre (Bibliothèque Historique de la Ville de Paris, MS C.P. 3509, ff 87-9); Chambers, Michael Moore, p. 110.28 B. de l'A., Archives de la Bastille, MS 10602, ff 92-4. See Chambers, Michael Moore, pp 110-11. 


\section{Interrogatoire du Sr de Barneville, prêtre, jeudi 14 juillet 1712 dans la salle du château de la Bastille. Interrogé sur son nom, âge, qualité, pays et demeure.}

A dit après avoir mis les mains sur la poitrine et promis de dire verité, qu'il se nomme Mathieu Barneuville et par changement de Barneville, agé de cinquante trois ans, prêtre du diocèse de Dublin en Irlande, natif de Grace Dieu à sept miles de Dublin et qu'il demeurait, lorsqu'il a été arrêté et conduit dans ce château [de la Bastille], au Collège de Boncourt. ${ }^{29}$

\section{Pourquoy il a changé son nom de Barneuville en celui de Barneville}

A dit que c'est un religieux capucin qui a causé ce changement, lui ayant fait entendre que la famille de lui (répondant) était originaire de Basse Normandie et portait anciennement le nom de Barneville. ${ }^{30} \mathrm{Il}$ a engaga le répondant à prendre le nom.

\section{Comment se nomme ce capuchin et d'où il le connait}

A dit que ce capucin est son cousin et qu'il se nommait de Barneville. ${ }^{31}$ Ajoute le répondant que ce capuchin, qui était commissaire général des capucins d'Irlande, est mort il y a environ vingt ans. ${ }^{32}$

29 The Collège de Boncourt on the rue Bordelle was very close to the rue de la Harpe where the Irish College was situated. See L'Abbé Lebeuf, Histoire de la ville et de toute le diocèse de Paris $(5$ vols, Paris, 188393), i, pp 130, 253. It was not one of the university's colleges de plein exercise in which public courses were taught. Founded in 1353 as a residence for university students from Flanders, the college was small and resembled a hostel. In 1638 , the then superior of the Irish College community, Tyrrell, and those under his direction, were said to be resident in this college. Irish ties with the Collège de Boncourt date back to at least 1617 when Malachy O'Kelly was professor of philosophy there. See L.W.B. Brockliss and Patrick Ferté, 'Prosopography of Irish clerics in the Universities of Paris and Toulouse, 1573-1792' in Arch. Hib., lviii (2004), p. 35, no. 223, pp 89-90, no. 743. My thanks to Priscilla O'Connor for this information regarding Tyrrell's residence. 30 The family name was de Barneval in the medieval period. The first of the family to arrive in Ireland was Sir Michael de Berneval or Barneval who landed at Berehaven, County Cork, allegedly before Strongbow reached Leinster. He was the direct descendant of Alanus de Barneval, the companionin-arms of William the Conqueror. See Bernard Burke, A genealogical history of the dormant, abeyant, forfeited, and extinct peerages of the British Empire (London, 1866 edn.), p. 23. 3I This was Barnabas Barnewall, OFM, Cap., reader of divinity in France and superior of the Capuchins in Ireland. A member of the Crickstown, County Meath branch of the family and a relative of the Flemings of Slane, Barnabas was responsible for conveying the orphaned children of Randall Fleming, Lord Slane and his wife Penelope to France where Michael Moore acted as their legal guardian and provided them with a catholic education. Michael Moore (c.1639-1726), priest, philosopher and educationalist was the first Catholic provost of Trinity College, Dublin and the only Irish rector of the University of Paris (1701). He was well connected with a wide circle of Catholic families from the Pale and was a close associate of both Matthew and Barnabas Barnewall. See Canice Mooney, OFM, Irish Franciscans and France (Dublin and London, 1964) p. 109; Brockliss and Ferté, 'Prosopography', p. 107, no. 907; Elizabethanne Boran, 'Michael Moore' in H.C.G. Matthew and Brian Harrison (eds), Oxford dictionary of national biography, 38 (Oxford, 2004), pp 903-04; Liam Chambers, 'Michael Moore' in Thomas Duddy (ed.), Dictionary of Irish philosophers (Bristol, 2004), pp 241-44; idem, Michael Moore (Dublin, 2005). 32 Barnabas Barnewall is likely to have died earlier than c.1692. 


\section{S'il $y$ a longtemps que le repondant est en France}

A dit qu'il y est venu à l'âge de quinze ans avec un ecclésiastique irlandais nommé [Valois?] qui lui avait été donné par sa mère pour le conduire en France. Son père, qui était un gentilhomme Irlandais, était par lors décedé. Qu'ils sont arrivés à Paris. Il fut mis par cet ecclésiastique dans une communauté d'Irlandais dont le Sieur Michel33 était le supérieur. Et laquelle communauté était située près de la porte St Michel.

\section{S'il a fait ses études en France}

A dit qu'il les a toutes faites à Paris, suivant ses humanités au Collège des Grassins ${ }^{34}$, sa philosophie au Collège d'Harcourt ${ }^{35}$, et sa théologie en Sorbonne, sous les Docteurs Pirot ${ }^{36}$ et Desperiers.

\section{Ce qu'il devint après avoir fait sa théologie}

A dit qu'étant par lors âgé de vingt-cinq ans et sa mère lui ayant fait temoigné qu'elle désirait qu'il retournerait à Dublin, et lui en ayant envoyé de l'argent pour son voyage, il retourné auprès d'elle, après avoir reçu la tonsure par les mains de Mr l'évêque de Bethléem ${ }^{37}$, ayant eu à cet effet (le répondant) la demissorie de $\mathrm{Mr}$ l'évêque de Dublin $^{38}$ qui est le sien.

À quoy il s'occupa lorsqu'il fut retourné à Dublin auprès de sa mère et en quelle année a-t-il y retourné

A dit qu'il [a] retourné à Dublin vers les années mil-six-cent-quatre-vingt-cinq ${ }^{39}$ ou mil-six-cent-quatre-vingt-six et qu'il n'y fut pas plutôt arrivé que son évêque l'engagé à se disposer à prendre les ordres pour à quels parvenir il s'est mit en retraite chez un curé qui lui a donné les instructions nécessaires et après une année ou environ de retraite, il reçu successivement les ordres même, ceux de prêtre, par les mains de Mr l'évêque de Dublin.

33 Probably David Mulcahil, a priest of the diocese of Leighlin who was elected superior of Leinster clerics in Collège du Cardinal Lemoine in 1670. Mulcahil's name is sometimes spelled Michel or Michael in contemporary sources. See Bibliothèque Nationale, Paris, MS Fr. 21735, ff 264-319. My thanks to Priscilla O'Connor and Liam Chambers for this information. 34 The Collège des Grassins, rue des Amandiers, established c.1571. See Abbé Lebeuf, Histoire de la ville et de toute le diocèse de Paris (5 vols, Paris, 1883-93), i , p. 254. Several Irish clerics lectured in this college including Robert O'Kearney, humanities professor in the 1630 s and Michael Moore, who was professor of philosophy and deputy principal of the college in the 1670s. See Brockliss and Ferté, 'Prosopography', p. 49, no. 357, p. 107, no. 907. Several Irish clerics also studied there, notably in the mid- and late eighteenth century. See Brockliss and Ferté, ibid., p. 151, 1367, p. 155 , nos $1419-25$, p. 156 , nos $1429-31$, p. 157 , no. 1454 , p. 158 , nos $1464-67$, p. 159, no. 1468; Chambers, Michael Moore, pp 33-4. It is likely that it was here that Barnewall became acquainted with Moore. 35 The Collège de Harcourt, situated in close proximity to the Collège des Lombards, was established in 1280 . See Lebeuf, Histoire, p. 130 . 36 Edme. Pirot, French theologian $(1631-1713)$. He lectured in theology and was examiner of theological works and theses. He was quoted by the eminent jansenist scholar, Pierre Nicole (1625-95) in 1691 to justify the latter's jansenist idea of delectatio victrix. See MM Firman Didot, Nouvelle biographie générale, $x 1$ (Paris, 1866), pp 320-21; O'Leary, 'The Irish and jansenism', p. 41. 37 Bethléem was a dependent on the metropolitan see of Sens. 38 Patrick Russell (1629-92), archbishop of Dublin (1683-92). A native of Rush in north County Dublin, Russell was a near neighbour of Barnewall. See Matthew and Harrison (eds), Oxford dictionary of national biography, 48 (Oxford, 2004), p. 328. 


\section{ARCHIVIUM HIBERNICUM}

\section{S'il resta longtemps en Irlande après avoir esté ordonné prêtre}

A dit que Mr l'évêque de Dublin, ayant voulu le charger d'une grosse curé dans son diocèse, le répondant le pria de vouloir bien trouver bien qu'auparavant qu'il pris aucun emploi, il pût encore revenir en France pour y prendre les instructions qui lui étaient nécessaires pour soutenir l'importance de l'emploi qu'il désirait lui donner. Ce que cet évêque ayant agrée, le répondant revint en France avec la permission de sa mère, qui lui donna les secours nécessaires pour faire son voyage, et muni d'un sceau de son évêque.

\section{Si, après avoir été ordonné prêtre à Dublin, il y [a] célébré les saintes mystères} A dit qu'oui.

\section{En quelle année le repondant revint en France}

A dit qu'il revint à ce qu'il croit vers la fin de l'année mil-six-cents-quatre-vingtsix ou au commencement de mil-six-cents-quatre-vingt-sept..$^{\circ}$

Et qu'à son arrivée à Paris, il [est] entré en la maison d'un prêtre de la Mission de Saint-Lazare ${ }^{41}$, d'où on l'a determiné à aller faire les fonctions de vicaire au village de Mousson, près de Beaumont-sur-Oise, diocèse de Paris, où il demeura environ deux ou trois ans à la sollicitation de Messrs de Saint-Lazare qui en sont predicateurs.

\section{S'il a été vicaire dans d'autre paroisses}

A dit que non.

\section{Pourquoy il ne resta que deux ou trois ans dans l'exercise du vicariat de Mousson}

A dit que c'est parceque on l'engagé de venir à Paris prendre soins d'une communauté d'Irlandais, qui était nouvellement établie rue Honoré chevalier. ${ }^{42}$ Laquelle communauté n'ayant par ici subsistée plus d'une année, il entra ensuite à l'Oratoire ${ }^{43}$ par l'ordre de $\mathrm{Mr}$ son évêque, et par le conseil de son directeur, et y a demeuré l'espace de dix-huit ans ou environ.

\section{Dans quelles maisons de l'oratoire il a demeuré}

A dit qu'il a demeuré un an ou environ dans la maison de l'institution à Paris, cinq années en celle de Saint-Paul-aux-Bois ${ }^{44}$, diocèse de Soissons où il a fait les

39 In 1685 the situation of Irish Catholics improved (albeit temporarily) when in February, James II succeeded Charles II and the following month, Richard Talbot (created earl of Tyrconnell in June) became commander of regiments. 40 While the pope regularly appointed nominal deans of Christ Church cathedral in Dublin throughout the seventeenth century, in February 1687, a change of policy was initiated when the papacy made appointments to other posts in the cathedral chapter and Matthew Barnewall was made precentor. King James II was furious at the papal appointments and by May 1688 Barnewall's position had been filled by John Dempsy. See Chambers, Michael Moore, p. 54. 4I The Congregation of Priests of the Mission, founded by St Vincent de Paul, was dedicated to the evangelisation of people in rural areas. See http://www.newadvent.org/cathen/15434c.htm 42 On 23 January 1663, the Fathers of the Oratory in Paris acknowledged sale of annual rent on five of their houses situated on Rue Saint Honoré, adjoining the Oratory's church, to Edward Tyrrell. A doctor of theology in the Collège de Navarre, Tyrrell was superior of the community of Irish, who were resident in the College d'Arras in the parish of St Nicolas du Chardonet. In 1677 Irish clergy were granted use of the old Italian Collège des Lombards and from 1685 , the Leinster students became residents. 43 The French Congregation of the Oratory was founded in Paris at the beginning of the seventeenth century by Cardinal Pierre de Bérulle. situated south-east of Amiens. 
fonctiones curialles, de laquelle maison $\mathrm{Mr}$ l'évêque de Soissons ${ }^{45}$ le tira pour le faire directeur de son séminaire où après avoir demeuré pendant quatre ans, le général de l'Oratoire ${ }^{46}$ tira le repondant de cette maison et il l'envoya à Grenoble où il ne fut pas plutôt arrivé que $\mathrm{Mr}$ le Cardinal Le Camus ${ }^{47}$ lui donna la direction de son grand séminaire que le répondant a executé pendant six années, après lesquelles il alla par direction et l'agrément de son général et de $\mathrm{Mr}$ le Cardinal Le Camus qui, avant son départ, lui fit promettre de revenir au plutôt. À quoy le répondant obéit, n'ayant demeuré à Rome qu'un mois et étant ensuite revenu à Grenoble où le répondant forma un nouveau séminaire de jeunes clerics par ordre et sous la protection de Mr le Cardinal Le Camus: $4^{8}$ et après avoir dirigé ce séminaire pendant un an, il revint en la maison de l'Oratoire de Paris avec la permission de $\mathrm{M}$. Le Camus. Le répondant ayant formé le dessein de retourner en Irlande où il n'a pas néanmoins retourné par le conseil de plusieurs personnes à cause des persecutions qu'on y exerçait à l'ère contre les ecclésiastiques. ${ }^{49}$

Il se retira ensuite par l'ordre du père général en la maison des écoliers près de Paris, où, après avoir demeuré environ quatre mois, le Sieur Moore, Irlandais, le principal des artiers du Collège de Navarre, ${ }^{\circ}$ l'engaga de demeurer avec lui, en attendant que le temps et l'occasion d'eux y serait favorable pour retourner en Irlande comme il en avait formé le dessein, et demeura (le répondant) trois années dans le Collège de Navarre où on lui a donné le soin de la conduite des boursiers. ${ }^{51}$

\section{Ce que fit le répondant après avoir demeuré trois année au Collège de Navarre}

A dit qu'il alla à Rome dans le dessein de s'en retourner ensuite en Irlande.

\section{Ce qu'il alla faire à Rome et s'il $\gamma$ demeura longtemps}

A dit qu'il y demeura environ quinze mois et que sa principale vue lorsqu'il retourna à Rome fut d'y visiter les saints lieux, ce quil n'avait pu faire la première

45 Fabio Brulart de Sillery, bishop of Soissons (1690-1714). 46 Abel-Louis de Saint-Marthe, who resigned in 1696 . During his generalship, the congregation was greatly disturbed by jansenist controversies. 47 Le Camus, a former doctor of the Sorbonne, was appointed bishop of Grenoble in 1671 and was created cardinal on 2 September 1686. Although a long distance away from his jansenist friends in Paris, he continued to correspond with them and showed considerably loyalty to his former friends from the Oratory, the abbaye de la Trappe and Port-Royal, particularly prior to his becoming cardinal. These associations caused the French authorities to grow increasingly suspicious of Le Camus. $\quad 4^{8}$ Cardinal Le Camus was responsible for founding two seminaries, one in Grenoble and another in Saint-Martin-de-Miseré. See MM. Firman Didot, Nouvelle biographie générale, xxx (Paris, 1862), p. 173.49 In 1704, the 'Act to prevent the further growth of popery' and the 'Registration Act' were passed. These required that clergy register with clerks of the peace, limited their number to one per parish, and prohibited the entry of further priests into the kingdom. 50 Michael Moore was appointed principal of Arts students (mainly those studying philosophy) at the college in 1702 . Founded in 1304 by Jeanne de Champagne, the college was one of the oldest and most prestigious teaching institutions in France. It was unique among the Parisian collèges de plein exercise (which offered public courses) in that it provided instruction in theology as well as in the humanities and philosophy. See Boran, 'Michael Moore', p. 903; Chambers, 'Michael Moore' in Duddy (ed.), Dictionary of Irish philosophers, p. 242; Chambers, Michael Moore, pp 99-105. Several other Irish clerics lived, studied and lectured in this college, including James Wogan, professor of philosophy in the 1720s, Nicholas-Anthony O'Kenny, convictus at the college, John Plunkett, professor royal in theology from 1749 to 1786 , and Galterius Blake, who was resident in the college in 1726. See Brockliss and Ferté, 'Prosopography', p. 113, no. 964, p. 134, no. 1165 , p. 127 , no. 1102, p. 129, no. 1121. 51 Moore recruited Barnewall as an under-principal at the college from 1703 to 1706 to assist him in implementing his reform programme in that institution. See Chambers, Michael Moore, p. 111. 
fois qu'il y avait esté. Ajoute le répondant qu'ayant su de plusieurs Irlandais qu'il trouva à Rome qu'il n'y avait plus en Irlande qu'un seul évêque qui était celui de Cashel,,$^{52}$ lequel à cause de son grand âge ne pouvoit plus faire ses fonctiones, il crut d'avoit representé au pape le besoin où était l'église d'Irlande de pasteurs. ${ }^{53}$ Il revint ensuite à Paris.

Pourquoy il revint à Paris plutôt que de retourner en Irlande où il nous a dit que son dessein avoit esté de retourner lorsqu'il partit pour son voyage à Rome

A dit qu'on ne lui conseilla pas de retourner à cause de la guerre..$^{54}$

\section{A quoy il s'occupa à son retour de Rome}

A dit qu'une personne de piété le priée de vouloir bien prendre soin d'un hôpital fort negligé dans le faubourg de Senlis, ce qu'il accepta par ordre de Mr l'évêque et $\mathrm{y}$ demeura quinze mois après lesquels le $\mathrm{Sr}$ Abbé Gaillard ${ }^{55}$ engagea le répondant de visiter les pauvres du diocèse de Senlis, qu'il avait appris être dans un extrême besoin, ce que le répondant fit en ayant reçu l'ordre du Sr Abbé de Pruines, grand vicaire de l'évêque de Senlis, qui était par lors absent.

Combien de temps il a employé à la visite des pauvres du diocese de Senlis et s'y personne ne l'accompagnait dans cette visite

A dit qu'il a employé environ un mois à cette visite et qu'il était accompagné du $\mathrm{Sr}$ de St Jean, prêtre et ami du Sr Abbé Gaillard. Que pendant ce temps, ils y ont distribué quantité d'aumônes et des livres de piété que ledit Sr Abbé Gaillard leur donnait à cet effet.

Quels livres le répondant et le Sr de Saint Jean ont distribué aux pauvres du diocèse de Senlis

A dit que les seuls qu'ils y ont distribué sont des Nouveaux Testaments, des homélies, de heures, et de jours, des imitations de la traduction du Père Girard, jésuite, la sanctification des fêtes et dimanches, des avis aux pères et mères pour la bonne education des enfants et la vie de Jesus Christ.

Si lui répondant et ledit Sr de Saint Jean n'ont point étés dans d'autre diocèses que dans celui de Senlis

A dit qu'ils ont été aussi reprendre des aumônes et distribués des livres dans les diocèses de Sens, d'Auxerre, de Beauvais et de Soissons. Et que ça toujours a été ledit Abbé Gaillard qui les a employé et leur a remis les fonds pour cela.

52 Edward Comerford was provided to the archdiocese in November 1695 , consecrated archbishop on 28 June 1697 and died 21 February 1710. See T.W. Moody, F.X. Martin and F.J. Byrne (eds), A new history of Ireland, IX. Maps, genealogies, lists. A companion to Irish history, part II (Oxford, 1984), p. 355. 53 Given Comerford's advanced age and Barnewall's close association with his predecessor in Cashel, John Brenan (1677-93), who dispatched detailed reports regarding the state of the catholic church and laity to Rome, Barnewall may well have informally assumed the role of Comerford's messenger to the pope. 54 The war of the Spanish succession (1702-13). 55 Honoré Reynaud de Gaillard (1641-1727), orator and preacher, was confessor to Mary of Modena, wife of James II. Although not a member of the Port-Royal community, Gaillard displayed an adherence to the spirit of poverty advocated by de Saint-Cyran. See Lesaulnier and McKenna (eds), Dictionnaire, p. 435. 
S'ils ont fait ces démarches et ces distributions d'aumônes et des livres de l'agrément des évêques de ces diocèses

A dit qu'oui et que les certificats se retrouveront dans ses papiers.

S'il n'a pas distribué conjointement avec ledit Sr de Saint Jean des livres suspects sur la religion et principalement jansenistes

A dit qu'ils n'ont jamais distribué aucuns de ces livres qui eurent été contre la vue et l'inclination qu'ils avaient d'instruire, comme ils ont fait, les pauvres.

S'ils n'en ont pas distribué d'un traduction ou avec des nottes et des remarques qui n'étaient point approvées

A dit que leur attention particulière a été de n'en distribuer aucune qui ne fussent très approuvées.

S'il n'a point été en relation et en commerce avec quelques jansenistes

A dit qu'il n'a jamais été en relation n'y avait eu commerce avec aucune personne de ce parti, se souvient néamoins qu'il a environ seize à six-sept ans, étant à Grenoble, il a reçu une lettre du Père Quesnel, fort indifférente autant qu'il peut s'en souvenir à laquelle il n'a jamais fait aucun réponse.

S'il n'a pas écrit aux gens de la caballe et n'a pas reçu des lettres d'eux

A dit qu'il a toujours détesté et déteste encore toutes sortes de caballes, et que n'ayant jamais eu de relation n'y de commerce avec ces sortes de gens, il n'a eu gardé de leur écrire n'y d'en recevoir aucunes lettres.

Si le répondant n'a pas eu d'après relations avec le Père Quesnel et ses adherants soit de vue, voix ou par l'écrit et s'il ne leur a pas fait connaître et à d'autres qu'il fut d'avis des sentiments contraires aux décisions de l'église sur la matière de la grâce

A dit que non, qu'il n'a reçu qu'une seule lettre du Père Quesnel pendant que lui (répondant) était à Grenoble, ainsi qu'il nous l'a ci-devant declarée que la verité il n'a pas signé le formulaire mais qu'on n'en lui a pas présenté. Ajoute qu'il est près de signer de soutenir toutes les décisions de l'église.

Lecture faite au répondant de les interrogatoires et reprouvées ..... 